Is the villin defect described by Phillips and colleagues cause or consequence of the cholestatic liver disease? Unfortunately Phillips' group did not analyse the villin gene in their patients. Some infectious diseases may cause disruption of villin expression. ${ }^{8}$ Whether villin might also be a target for viruses is not known. Thus, although the villin defect described by Phillips and colleagues is highly interesting, the question remains whether this defect is genetic or perhaps acquired during embryogenesis. Also the possibility that the defect is secondary to cholestasis cannot be ruled out.

We have no conflict of interest to declare.

*Peter L M Jansen, Ekkehard Sturm

Department of Hepatology and Gastroenterology and *Department of Pediatrics, University Hospital Groningen, 9713 GZ Groningen, Netherlands (e-mail: p.l.m.jansen@int.azg.nl

1 Laurent J, Gauthier F, Bernard O, et al. Long-term outcome after surgery for biliary atresia: study of 40 patients surviving for more than 10 years. Gastroenterology 1990; 99: 1793-97.

2 Perlmutter DH, Shepherd RW. Extrahepatic biliary atresia: a disease or a phenotype? Hepatology 2002; 35: 1297-304.

3 Chen L, Goryachev A, Sun J, et al. Altered expression of genes involved in hepatic morphogenesis and fibrogenesis are identified by cDNA microarray analysis in biliary atresia. Hepatology 2003; 38 . 567-76

4 Friederich E, Vancompernolle K, Louvard D, Vandekerckhove J. Villin function in the organization of the actin cytoskeleton: correlation of in vivo effects to its biochemical activities in vitro. f Biol Chem 1999; 274: 26751-60.

5 Ferrary E, Cohen-Tannoudji M, Pehau-Arnaudet G, et al. In vivo, villin is required for $\mathrm{Ca}(2+)$-dependent $\mathrm{F}$-actin disruption in intestinal brush borders. F Cell Biol 1999; 146: 819-30.

6 Pinson KI, Dunbar L, Samuelson L, Gumucio DL. Targeted disruption of the mouse villin gene does not impair the morphogenesis of microvilli. Dev Dyn 1998; 211: 109-21.

7 Athman R, Louvard D, Robine S. Villin enhances HGF-induced actin cytoskeleton remodeling in epithelial cells. Mol Biol Cell Aug 22, 2003. DOI: $10.1091 / \mathrm{mbc} . \mathrm{E} 03-02-0091$.

8 Lauwaet T, Oliveira MJ, Callewaert B, et al. Proteolysis of enteric cell villin by Entamoeba histolytica cysteine proteinases. f Biol Chem 2003; 278: 22650-56.

9 Athman R, Louvard D, Robine S. The epithelial cell cytoskeleton and intracellular trafficking III: how is villin involved in the actin cytoskeleto dynamics in intestinal cells? Am F Physiol Gastrointest Liver Physiol 2002; 283: G496-G502.

\section{Urban health: a new discipline}

City living is a reality for many and is rapidly becoming so for most of the world's population. More than half the world's population will be living in urban areas before the end of this decade and nearly two-thirds will live in urban areas within 30 years. $^{1}$ Although North America and Europe are the world's most urbanised regions, most of the global urban population is on other continents. In 2000, the number of urban dwellers in the least urbanised region, Asia, was already greater than the urban population in North America and Europe combined, and most of the growth in urban populations will take place in less wealthy regions, particularly in Asia and Africa. ${ }^{2,3}$

Why should health professionals take a particular interest in urban living? Urban living has long been associated with health, both positively and negatively. In the world's wealthier countries, cities in the 19th and at the turn of the 20th century were plagued by infectious diseases associated with crowding. ${ }^{4}$ Epidemics of influenza, typhus, and tuberculosis killed millions of people in cities with poor sanitation and squalid living conditions. After a revival in the quality of most cities in the developed world in the middle of the 20th century, recent history has seen growing disparities in the health of urban residents compared with suburban and rural populations. The emerging HIV epidemic and a rise in violence in the 1980s exacerbated the burden of disease in many cities., ${ }^{5,6}$ Terms such as urban penalty have been proposed to account for this excess burden of disease. ${ }^{7}$ In less wealthy countries, infectious diseases were the largest contributors to morbidity and mortality in urban areas throughout the 20th century. ${ }^{8,9}$ However, at the end of that century, a growing middle-class in many of these cities was accompanied by a rise in chronic diseases, resulting in a double burden of disease affecting many of the world's most populous cities. ${ }^{8}$ On the other hand, many public-health interventions have been implemented primarily in cities, and specialised medical care is often found in cities rather than in less urban areas.

Although public-health interventions have long had a role in the control of disease in cities, ${ }^{4,5}$ research about the features of modern urban areas and the facets of urban living that influence health has been sparse. During the past several decades, much research has focused on documenting the burden of disease in inner-city areas. Different academic disciplines have studied the health of marginalised groups without fully exploring the role that the urban context itself played both in the groups' marginalisation and in shaping the health of these populations. For example, much research about the health of drug users, particularly into the spread of HIV and other infectious diseases, has explored individual risk-behaviours that are important within this group, but often with a limited focus on how living in cities affected these risk behaviours.

A small but growing body of work now recognises that the role that the urban environment has in shaping health and disease is itself of interest. ${ }^{10}$ Understanding the urban factors that are risk or protective factors for health can capitalise on the positive aspects of urban living and lead to the development of appropriate interventions and preventive measures. Given the growing predominance of urban living, interventions that take into account features of the urban environment have the potential to be widely applicable and to influence the health of vast numbers of people.

However, there is a long way to go before health professionals can understand features of city living well enough to be able to improve the health of urban dwellers. There are several barriers to the study of urban health as a cogent discipline. First, urban health is currently the domain of multiple disciplines. Urban planners can bring to the field perspectives about city design and how this might affect behaviour and even wellbeing in cities. Urban sociologists study interactions in densely populated cities. Epidemiologists document the burden of disease in urban areas and the factors associated with those diseases. Unfortunately, these disciplines seldom speak the same academic language and tremendous barriers exist to true cross-disciplinary work. There is no common vocabulary for urban health. Different disciplines have used words such as urbanism, urbanisation, and urbanicity to represent different concepts, hindering the ability of different disciplines to learn from one another. Second, and perhaps curiously, although there have recently been several academic exercises devoted to rural health, there has been little effort concentrated at bringing together researchers and practitioners from different disciplines who can illuminate understanding of key issues in the discipline.

A meeting ${ }^{11}$ at the New York Academy of Medicine, New York City, on Oct 15-17, 2003, co-sponsored by several academic and public-health institutions worldwide, will be the second in a series attempting to lay the foundations for the proposed discipline of urban health. Questions that will be addressed include: what is urban health and how should different aspects of urban living be considered as potential 
determinants of health? What are the fundamental characteristics of the urban physical and social environment that might affect health? What are the public-health interventions that could improve the health of urban populations? And how can urban health become consolidated as a discipline, and how can a body of theory and practice be taught effectively to health professionals? We are co-chairs of the second international conference on urban health.

\section{* David Vlahov, Sandro Galea}

Center for Urban Epidemiologic Studies, New York Academy of Medicine, New York City, NY 10029, USA

(e-mail: dvlahov@nyam.org)

1 United Nations Population Division. World urbanization prospects: the 1999 revision. New York: United Nations Population Division, 2000.

2 Satterthwaite D. Coping with rapid urban growth. London: Royal Institution of Chartered Surveyors, Leading Edge Series, September, 2002: http://www.rics.org/downloads/research_reports/ urban growth.pdf (accessed Sept 29, 2003).

3 Gelbard A, Haub C, Kent M. World population beyond six billion. Popul Bull 1999; 54: 1-44.

4 Rosen G. History of public health. Baltimore: Johns Hopkins University Press, 1993.

5 Freudenberg N, Silver D, Carmona JM, Kass D, Lancaster B, Speers $M$. Health promotion in the city: a structured review of the literature on interventions to prevent heart disease, substance abuse, violence and HIV infection in US metropolitan areas, 1980-1995. f Urban Health 2000; 77: 443-57.

6 Cornish JW, O'Brien CP. Crack cocaine abuse: an epidemic with many public health consequences. Annu Rev Public Health 1996; 17: 259-73.

7 Gould WT. African mortality and the new 'urban penalty'. Health Place 1998; 4: 171-81.

8 McMichael AJ. The urban environment and health in a world of increasing globalization: issues for developing countries. Bull World Health Organ 2000; 78: 1117-26.

9 Murray CJ, Lopez AD. Mortality by cause for eight regions of the world: Global Burden of Disease Study. Lancet 1997; 349: 1269-76.

10 Vlahov D, Galea S. Urbanization, urbanicity, and health. f Urban Health 2002; 79 (suppl 1): S1-S12.

11 The International Society for Urban Health. The second international conference on urban health, Oct 15-18, 2003: http://www.isuh.org/ conference.html (accessed Sept 26, 2003).

\section{Putting Jenner back in his place}

Debate about what statues should or should not be in one of the most famous public places in the world, Trafalgar Square in London, recently resumed with the announcement by the Greater London Authority of the sculptors who have been shortlisted to create a contemporary artwork to occupy an empty plinth. ${ }^{1}$ The square has recently been remodelled, and the Mayor of London advocates the erection of a permanent statue of Nelson Mandela in it. ${ }^{2}$ But perhaps the time has come to reverse the unceremonious eviction from the square of the statue (figure) of an international medical hero (which used to be on different plinth).

The development of an effective form of vaccination

Edward Jenner's statue in Kensington Gardens, London, UK against smallpox just over 200 years ago by Edward Jenner, a physician and natural scientist in the west of England, was the decisive breakthrough that laid the basis for the eventual eradication of the disease. By the early 1950s smallpox was no longer endemic in Europe, but there were still 50 million new cases worldwide each year. ${ }^{3}$ Smallpox was devastating; about $30 \%$ of those affected died of the disease and the rest were left scarred and often blinded. Less than 30 years later the disease was declared eradicated by WHO after a global vaccination programme. WHO has delayed the destruction of the remaining stocks of variola virus so that further research can be done if needed.

Concern about the possible deliberate release of smallpox as a form of bioterrorism has led to the development of contingency plans in several countries. In England the plan includes the vaccination of teams of health professionals who would be called on if deliberate release of the virus was suspected. ${ }^{4}$ The principles of the management of a smallpox incident would still be isolation of cases and vaccination of contacts. So, after 200 years, the pioneering work of Jenner remains the basis of public protection against this important disease.

Jenner was perhaps the first international medical hero and was appropriately honoured in many countries worldwide. But his memory has been neglected in his own country. ${ }^{5}$ Jenner was born and died in the village of Berkeley in Gloucestershire, where, in the course of his medical practice, he developed vaccination. The house where he lived contains an impressive museum dedicated to his memory. ${ }^{6}$ A committed international effort, in which the USA and Russia were the major financial contributors, led to the erection of a statue of Jenner in Trafalgar Square in 1858 , some 36 years after his death. The statue was not permitted to remain in the square however, since it was felt that such a prominent place should be reserved for heroes of the process of taking lives in the course of gaining martial glory, rather than for a doctor engaged in saving lives. Despite opposition from the British Medical fournal, ${ }^{7}$ after only 4 years the statue was banished to Kensington Gardens in London.

The eradication of smallpox in 1980 is arguably the greatest achievement of humankind. How fitting it would be if the memory of the man whom we have to continue to thank for keeping us safe should be honoured by putting his statue back where it rightly belongs.

We have no conflict of interest to declare.

\section{* Gabriel Scally, Isabel Oliver}

Regional Public Health Group, Government Office for the South West, Bristol BS1 6ED, UK (GS); and Avon Health Protection Unit, Bristol (IO) (e-mail: gscally.gosw@go-regions.gsi.gov.uk)

1 London. Shortlist of international artists announced for Trafalgar Square's 4th Plinth. July 25, 2003: http://www.london.gov.uk/view_ press_release.jsp?releaseid=1873 (accessed Sept 30, 2003).

2 London. Mayor calls on Westminster planning committee to recognise achievements of Mandela. May 7, 2003:

http://www.london.gov.uk/view_press_release.jsp?releaseid $=1732$ (accessed Sept 30, 2003).

3 Fenner F, Henderson DA, Arita I, Jezek Z, Ladnyi ID. Smallpox and its eradication. Geneva: WHO, 1988: http://www.who.int/emc/diseases/ smallpox/smallpoxeradication.htlm (accessed July 23, 2003).

4 Department of Health. Interim guidelines for smallpox response and management in the post-eradication era, 2002: http://www.doh.gov.uk/ epcu/cbr/biol/smalist.htm (accessed Aug 14, 2003).

5 Empson J. Little honoured in his own country: statues in recognition of Edward Jenner MD FRS. $\mathcal{F}$ R Soc Med 1996; 89: 514-18.

6 The Jenner Museum. http://www.jennermuseum.com (accessed Aug 13, 2003).

7 Leading article. Where shall we put the statue of Jenner? BMF 1858; I: 395. 